\title{
ANTHOCYANINS OF FRUITS AND VEGETABLES - THEIR OCCURRENCE, ANALYSIS AND ROLE IN HUMAN NUTRITION
}

\author{
Marcin HORBOWICZ ${ }^{1}$, Ryszard KOSSON ${ }^{2}$, Anna GRZESIUK ${ }^{1}$, Henryk DĘBSKI $^{1}$ \\ ${ }^{1}$ University of Podlasie, Department of Plant Physiology and Genetics \\ Prusa 12, 08-110 Siedlce, Poland \\ ${ }^{2}$ Research Institute of Vegetable Crops, \\ Konstytucji 3 Maja 1/3, 96-100 Skierniewice, Poland
}

Received: February 6, 2008; Accepted: April 10, 2008

\begin{abstract}
Summary
Anthocyanins are one of the largest and most important group of watersoluble pigments in most species in the plant kingdom. They are accumulated in cell vacuoles and are largely responsible for diverse pigmentation from orange to red, purple and blue in flowers, fruits, such as: blackberry, red and black raspberries, blueberries, bilberries, cherries, currants, blood orange, elderberries, grapes, and vegetables such as: red onion, radish, red cabbage, red lettuce, eggplant, red-skinned potato and purple sweet potato. Anthocyanins in fruits and vegetables are present in glycosylated forms. The qualitative and quantitative determination of anthocyanins in plant can be performed by classical (spectrophotometric) or contemporary methods - HPLC coupled with a various types of mass spectrometers or NMR apparatus. Anthocyanins are widely ingested by humans, mainly due to consumption of fruits, vegetables and red wines. Depending on the nutritional habits, the daily intake of anthocyanins for individuals has been estimated from several milligrams to hundreds of milligrams per person. Anthocyanins as well as other flavonoids occuring in fruits, and vegetables are protective against a variety of diseases, particularly cardiovascular disease and some types of cancer. Also the visual acuity can be markedly improved through administration of anthocyanin pigments to animals and humans.
\end{abstract}

key words: anthocyanins, fruits, vegetables, occurrence, analytical methods, nutrition value

\section{INTRODUCTION}

Anthocyanins are generally accepted as the largest and most important group of water-soluble pigments in nature (Harborne 1998, Eder 2000, Takeoka \& Dao 2002). The word anthocyanin derived from two Greek words: anthos, which means flower, and kyanos, which means dark blue, reveals its important

Corresponding author:

e-mail: marcin.horbowicz@neostrada.pl

C) Copyright by RIVC 
characteristic as a natural colorant (Eder 2000, Delgado-Vargas et al. 2000, Delgado-Vargas \& Paredes-López 2003). Anthocyanins are accumulated in cell vacuoles and are responsible for diverse pigmentation from orange to red, purple and blue in flowers, fruits and vegetables. Often, these compounds also occur in leaves, stems, seeds, and other tissues. In general, pigments of pelargonidin and cyanidin derivatives produce red and purple color, respectively, whereas those of delphinidin show purple or blue color (Goto \& Kondo 1991).

Contributing to the colorful appearance of flowers, fruits and vegetables, anthocyanins help them to attract animals, leading to seed dispersal and pollination (Harborne \& Williams 2001). Mazza \& Miniati (1993) reported that anthocyanins might be important in protecting plants against ultraviolet-induced damage, as well. In addition, they play roles as anti-oxidants and in protecting DNA and the photosynthetic apparatus from high radiation fluxes (Gould 2004). Other possible functions of anthocyanins, such as the protection against cold stress or providing drought resistance, are associated with activities restricted to particular classes of plants (Chalker-Scott 1999).

\section{Chemical structures of anthocyanins}

The anthocyanidins are hydroxylated and methoxylated derivates of phenyl-2-benzopyrylium or flavylium salts, regarded as flavonoid compounds (Eder 2000). Their basic structure of the aglycone is a C-6 (A-ring)-C-3 (Cring)-C-6 (B-ring) carbon skeleton (shown in Fig. 1), figuring a chromane ring bearing a second aromatic ring $\mathrm{B}$ in position 2 . There is seventeen known naturally occurring anthocyanidins, but only six of them are common in higher plants - cyanidin $(\mathrm{Cy})$, peonidin $(\mathrm{Pn})$, pelargonidin $(\mathrm{Pg})$, malvidin $(\mathrm{Mv})$, delphinidin (Dp), and petunidin (Pt) (Eder 2000, Kong et al. 2003), with cyanidin being the most common (Harborne 1998). Structures of the main anthocyanidins are shown on Fig. 1. The differences in chemical structure of these six common anthocyanidins occur at the 3' and 5' positions of B-ring (Fig. 1).

Due to presence of eight conjugated double bonds carrying a positive charge, anthocyanins are intensely red or orange under acidic conditions (below $\mathrm{pH} 2$ ), but in higher $\mathrm{pH}$ they are colorless and in alkaline conditions change their colour into bluish (Fig. 2). Intensity and type of the color of anthocyanins is affected by the number of hydroxyl and methoxyl groups: if more hydroxyl groups, then the color goes toward a more bluish shade; if more methoxyl groups, then redness is increased (Heredia et al. 1998, Delgado-Vargas \& Paredes-López 2003).

The aglycones (anthocyanidins) are found in fresh plant material only in trace quantities, because they are quite unstable (Clifford 2000, Prior 2004). The glycosides of anthocyanidins are called anthocyanins. Usually anthocyanidin glycosides are 3-monoglycosides and 3,5-diglycosides as was shown in Fig. 3. The most common sugar of anthocyanidin glycosides is glucose (Fig. $3 \mathrm{~B}$ ), but occur also rhamnose, xylose, galactose, arabinose, as well as rutinose (6-O-L-rhamnosyl-D-glucose) (Fig. 3A). 


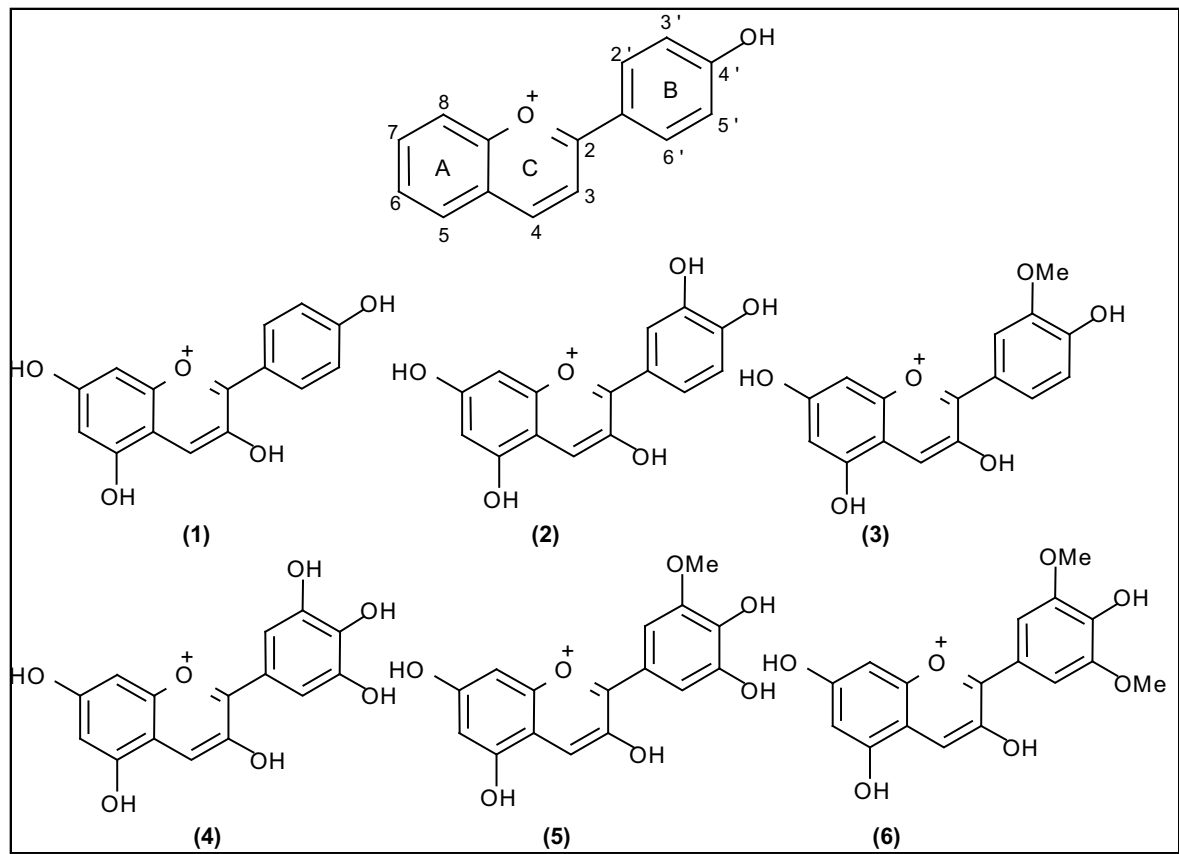

Fig. 1. Chemical structures of main anthocyanidins: 1 - pelargonidin (Pg); 2 - cyanidin (Cy); 3 - peonidin $(\mathrm{Pn}) ; 4$ - delphinidin (Dp); 5 - petunidin (Pt); 6 - malvidin (Mv)

The sugar residues may be further acylated with organic acids (Mazza \& Miniati 1993, Giusti et al. 1998, Eder 2000). Common acylating agents include cinnamic acid derivatives such as caffeic, p-coumaric, ferulic and sinapic acid, as well as a range of aliphatic acids such as acetic, malic, malonic, oxalic, and succinic. Since each anthocyanidin may be glycosylated and acylated by various sugars and acids at different positions, a great number of chemical combinations exist (Harborne 1998, Delgado-Vargas \& Paredes-López 2003). It was estimated that more than 400 anthocyanins had been found in nature (Mazza \& Miniati 1993). Such variations together with the $\mathrm{pH}$ dependent and chelating metal ion dependent color change reasonably elucidated the great variation of natural colors (Hou 2003).

Stability of anthocyanins can be enhanced through so called copigmentation. Acylated anthocyanins containing two or more aromatic acyl groups may affect the color through a mechanism called intramolecular copigmentation (Dangles et al. 1993, Mazza \& Miniati 1993, Harborne \& Williams 2001). Anthocyanins also interact with other flavonoids and related compounds to produce an increase in color intensity and a shift in the wavelength of maximum absorbance toward higher wavelengths. Such a phenomenon is called intermolecular copigmentation, which can take place in acidic, neutral and even slightly alkaline aqueous solution (Mazza \& Miniati 1993). Copigmentation plays a crucial role in wine ageing and maturation (Brouillard \& Dangles 1994). 


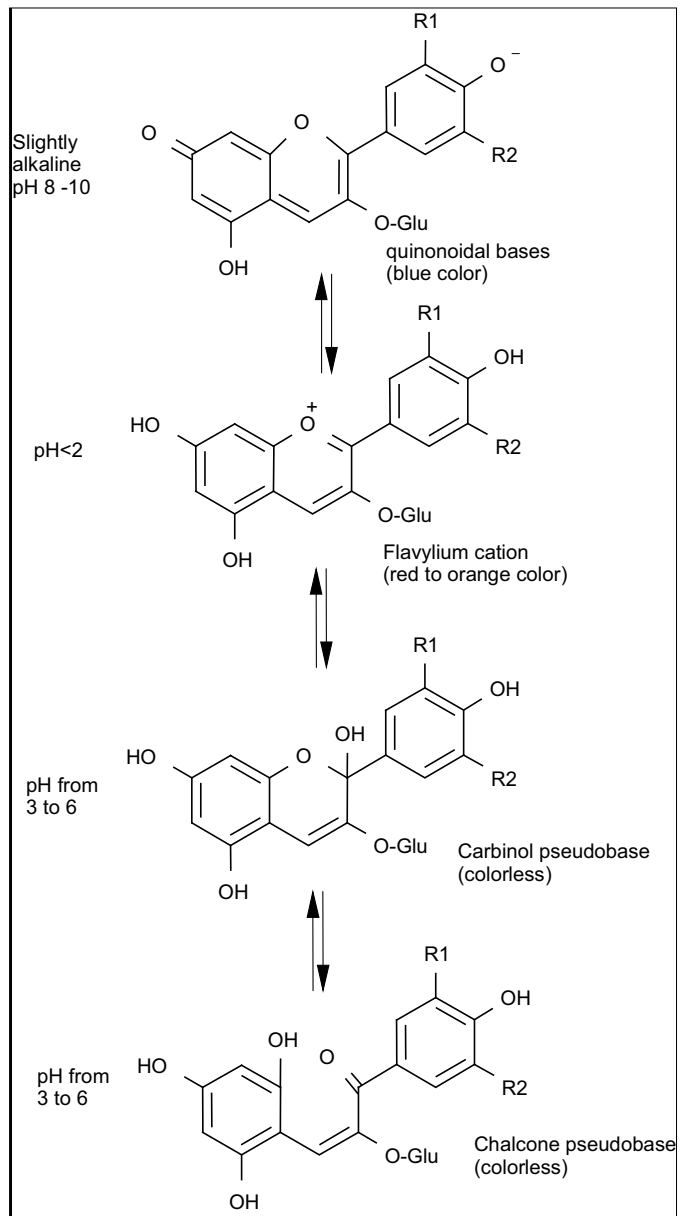

Fig. 2. Effect of $\mathrm{pH}$ conditions on color of anthocyanins or products its conversion (Brouillard 1982 - modified).

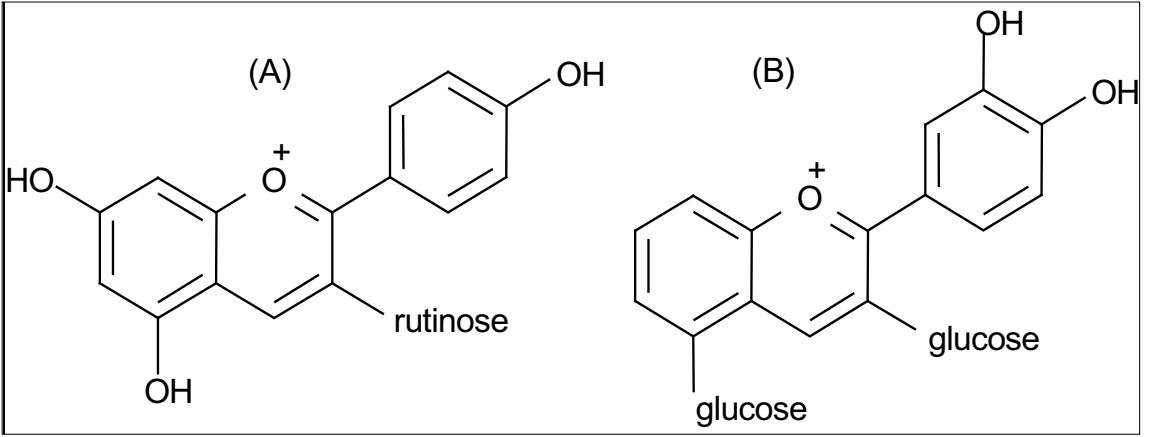

Fig. 3. Chemical structures of pelargonidin 3-rutinoside (A) and cyanidin 3,5diglucoside (B) 


\section{Distribution and content of anthocyanins in fruits and vegetables}

Anthocyanins are water-soluble and vacuolar pigments found in most species in the plant kingdom (Harborne 1998). They are accumulated in fruit plants such as blackberry, red and black raspberries, blueberries, bilberries, cherries, currants, blood orange, elderberries, grapes, and vegetables such as: red onion, radish, red cabbage, fennel, red lettuce, eggplant, red-skinned potato and purple sweet potato (Table 1). Anthocyanins can be found in all parts of the plants. Although they are accumulated mostly in flowers and fruits, but are also present in leaves, stems and storage organs (Brouillard 1982, Delgado-Vargas \& Paredes-López 2003). Among different plants or even cultivars in the same plant, the total anthocyanin content varies considerably, affected by genes, light, temperature, and agronomic factors. Presented in Table 1 data shown, in general, that level of anthocyanins in fruits is much higher than in vegetables. Among fruits richest in anthocyanins are various berries and black currants. There is only one common vegetable which contain high level of anthocyanins - eggplant (Table 1).

Table 1. Total anthocyanin content in selected common fruits and vegetables

\begin{tabular}{lcl}
\hline Fruit or vegetable & $\begin{array}{c}\text { Total anthocyanin } \\
\text { content }\left(\mathrm{mg} \cdot \mathrm{kg}^{-1}\right)\end{array}$ & \multicolumn{1}{c}{ Literature sources } \\
\hline Apple (peel) & $100-2160$ & Eder 2000 \\
\hline Bilberry & 4600 & Eder 2000 \\
\hline Blackberry & $820-1800$ & Eder 2000, Clifford 2000 \\
\hline Blueberry & $825-5300$ & $\begin{array}{l}\text { Timberlake \& Henry 1988, Eder 2000, } \\
\text { Clifford 2000 }\end{array}$ \\
\hline Cherry & $3500-4500$ & Eder 2000 \\
\hline Chokeberry & $5060-10000$ & Clifford 2000 \\
\hline Cranberry & $460-2000$ & Timberlake \& Henry 1988, Eder 2000 \\
\hline Elderberry & $2000-15600$ & Eder 2000, Clifford 2000 \\
\hline Grape (red) & $300-7500$ & Timberlake \& Henry 1988, Clifford 2000 \\
\hline Grape (blue) & $80-3880$ & Eder 2000 \\
\hline Orange, blood & 2000 & Clifford 2000 \\
\hline Plum & $19-250$ & Timberlake \& Henry 1988, Eder 2000 \\
\hline Raspberry (red) & $100-600$ & Timberlake \& Henry 1988, Eder 2000, \\
\hline Raspberry (black) & $763-4277$ & Timberlake \& Henry 1988, Clifford 2000 \\
\hline Strawberry & $127-360$ & Timberlake \& Henry 1988, Clifford 2000 \\
\hline Currant (black) & $1300-4000$ & Timberlake \& Henry 1988, Clifford 2000 \\
\hline Currant (red) & $119-186$ & Clifford 2000 \\
\hline Cabbage (red) & 250 & Timberlake \& Henry 1988 \\
\hline Eggplant & 7500 & Clifford 2000 \\
\hline Radish (red) & $110-600$ & Giusti et al. 1998 \\
\hline Onion (red) & up to 250 & Timberlake \& Henry 1988 \\
\hline Rhubarb & up to 2000 & Timberlake \& Henry 1988 \\
\hline
\end{tabular}


Table 2. Content of main anthocyanidins in selected fruits (from database: USDA 2007) (mg. $100 \mathrm{~g}^{-1}$ fresh weight)

\begin{tabular}{|c|c|c|c|c|c|c|c|}
\hline Species & $\mathrm{Cy}$ & $\mathrm{Pg}$ & $\mathrm{Mv}$ & $\mathrm{Pt}$ & $\mathrm{Pn}$ & Dp & Literature sources \\
\hline $\begin{array}{l}\text { Apples } \\
\text { Gala } \\
\text { Golden delicious } \\
\text { Red delicious } \\
\end{array}$ & $\begin{array}{l}1.5 \\
2.0 \\
6.1\end{array}$ & & & & & & $\begin{array}{l}\text { Arabbi et al. 2004, } \\
\text { Franke et al. } 2004 \text {, } \\
\text { Harnly et al. 2006, } \\
\text { Wu et al. } 2006\end{array}$ \\
\hline Bananas & & & & & & 7.4 & Harnly et al. 2006 \\
\hline Blackberries & 90.3 & 0.2 & & & & & $\begin{array}{l}\text { Fan-Chiang \& Wrol- } \\
\text { stad } 2005, \\
\text { Harnly et al. } 2006, \\
\text { Wu et al. } 2006\end{array}$ \\
\hline Bilberry & 112.6 & & 54.4 & 51.1 & 51.1 & 161.9 & Kahkonen et al. 2003 \\
\hline Blueberries & 17.0 & & 61.4 & 26.4 & 11.4 & 47.4 & $\begin{array}{l}\text { Franke et al. 2004, } \\
\text { Gao \& Mazza 1994a }\end{array}$ \\
\hline Chokeberry & 435.8 & 1.4 & & & & & $\begin{array}{l}\text { Slimestad et al. } 2005, \\
\text { Wu et al. } 2004\end{array}$ \\
\hline Cranberries & 41.8 & & 0.3 & & 42.1 & 7.7 & $\begin{array}{l}\text { Harnly et al. } 2006, \\
\text { Wu et al. } 2006\end{array}$ \\
\hline Currant, black & 85.6 & 1.2 & & 3.9 & 0.7 & 181.1 & $\begin{array}{l}\text { Iversen } 1999, \\
\text { Kahkonen } \text { et al. } 2003 \text {, } \\
\text { Maatta et al. } 2003 \text {, } \\
\text { Wu et al. } 2004\end{array}$ \\
\hline Currant, red & 12.9 & & & & & & $\begin{array}{l}\text { Maatta et al. } 2003 \text {, } \\
\text { Wu et al. } 2004\end{array}$ \\
\hline Elderberries & 758.5 & 1.1 & & & & & $\begin{array}{l}\text { Kaack \& Austed 1998, } \\
\text { Wu et al. } 2004\end{array}$ \\
\hline Red grape & 1.5 & 1.1 & 34.7 & 2.9 & 2.1 & 3.7 & $\begin{array}{l}\text { Franke et al. } 2004, \\
\text { Revilla et al. } 1998, \\
\text { Wu et al. } 2006\end{array}$ \\
\hline Plums & 39.7 & & & & & & $\begin{array}{l}\text { Franke et al. } 2004, \\
\text { Harnly et al. } 2006, \\
\text { Wu et al. } 2006\end{array}$ \\
\hline Pears & 12.2 & & & & & & Harnly et al. 2006 \\
\hline Raspberries, red & 35.8 & 1.9 & 0.7 & & & 0.3 & $\begin{array}{l}\text { Ancos et al. } 1999, \\
\text { Mullen et al. } 2002 \text {, } \\
\text { Wu et al. } 2006\end{array}$ \\
\hline Raspberries, black & 323.5 & & & & & & Wu et al. 2006 \\
\hline Sour cherries & 6.6 & & & & & & Wang et al. 1997 \\
\hline Sweet cherries & 75.2 & 0.5 & & & 4.5 & & $\begin{array}{l}\text { Gao \& Mazza } 1994 a, \\
\text { Harnly et al. } 2006, \\
\text { Wu et al. } 2006\end{array}$ \\
\hline Strawberries & 2.0 & 31.3 & & & & 0.3 & $\begin{array}{l}\text { Franke et al. } 2004, \\
\text { Garcia-Vigera etal. } 1998 \text {, } \\
\text { Harnly et al. } 2006, \\
\text { Wang et al. } 2002 \text {, } \\
\text { Wang \& Lin } 2003 \text {, } \\
\text { Wu et al. } 2006\end{array}$ \\
\hline
\end{tabular}


Mean distribution of the six most common anthocyanidins in the edible parts of plants is following: cyanidin $(50 \%)$, pelargonidin $(12 \%)$, peonidin (12\%), delphinidin (12\%), petunidin (7\%), and malvidin (7\%) (Kong et al. 2003). The three non-methylated anthocyanidins: cyanidin (Cy), delphinidin $(\mathrm{Dp})$ and pelargonidin $(\mathrm{Pg})$ are the most widespread in nature. Most species contain a limited number of anthocyanin pigments (apples, plums, pears), but in some cases - like red grapes, may contain a mixture of more than 20 pigments (Clifford 2000). Overall, cyanidin aglycone occurs in about $90 \%$ of fruits, and is the most frequently appearing aglycone (Prior 2004) (Tables $2 \& 3$ ).

Anthocyanins in fruits and vegetables are present in glycosylated forms. However, many of the analytical procedures convert the glycosides into aglycones and thus results in Tables 2 and 3 are reported as aglycones. Therefore results summarized in both tables are after conversion the glycoside values into aglycone forms based on molecular weight to make data consistent across the database.

In plants the following three classes of anthocyanidin glycosides are common: 3-monoglycosides, 3-diglycosides, and 3,5-diglycosides. 3-Glycosides occur about two and half times more frequently than 3,5-diglycosides (Kong et al. 2003). Considering that glucoside form is the most abundant comparing to other glycosides, cyanidin 3-glucoside is the most widespread anthocyanin in nature (Prior 2004, Kong et al. 2003).

Table 3. Content of main anthocyanidins in selected vegetables (from database: USDA 2007) (mg.100 ${ }^{-1}$ fresh weight)

\begin{tabular}{|c|c|c|c|c|c|c|c|}
\hline Species & $\mathrm{Cy}$ & $\mathrm{Pg}$ & $\mathrm{Mv}$ & $\mathrm{Pt}$ & $\mathrm{Pn}$ & $\mathrm{Dp}$ & Literature sources \\
\hline Bean, black & & & 6.5 & 9.6 & & 12.0 & $\begin{array}{l}\text { Franke et al. } 2004, \\
\text { Romani et al. } 2004 \text {, } \\
\text { Wu et al. } 2006\end{array}$ \\
\hline Bean, red & 1.2 & 2.4 & & & & & Wu et al. 2006 \\
\hline Cabbage, red & 72.9 & & & & & 0.1 & $\begin{array}{l}\text { Franke et al. } 2004, \\
\text { Wu et al. } 2006\end{array}$ \\
\hline Eggplant & & & & & & 13.8 & $\begin{array}{l}\text { Franke et al. } 2004, \\
\text { Wu et al. } 2006\end{array}$ \\
\hline Lettuce, red & 2.8 & & & & & & $\begin{array}{l}\text { Harnly et al. } 2006, \\
\text { Wu et al. } 2006\end{array}$ \\
\hline Onion, red & 6.2 & & & & 1.2 & 2.3 & $\begin{array}{l}\text { Arabbi et al. } 2004, \\
\text { Franke } \text { et al. } 2004, \\
\text { Wu } \text { et al. } 2006, \\
\text { Gennaro et al. } 2002, \\
\text { Ferreres } \text { et al. } 1996\end{array}$ \\
\hline Radish & & 25.7 & & & & & $\begin{array}{l}\text { Harnly et al. } 2006, \\
\text { Wu et al. } 2006\end{array}$ \\
\hline
\end{tabular}

\section{Stability of anthocyanins}

Many factors, such like the $\mathrm{pH}$, temperature, light, presence of other phenolic compounds, enzymes, metal ions, sugars, ascorbic acid, and oxygen have 
impact on the stability of anthocyanins. In aqueous solution, anthocyanins undergo structural transformations that are $\mathrm{pH}-$ dependent (Fig. 2) (Brouillard et al. 1982). It has been found that four major anthocyanin forms exist in equilibria: the red flavylium cation, the blue quinonoidal base, the colorless carbinol pseudobase, and the colorless chalcone. At $\mathrm{pH}$ below 2, anthocyanins exist primarily in the form of the red flavylium cation. Process of a flavylium salt salvation in a slightly acidic or neutral aqueous solution results in formation of neutral and/or quinonoidal bases (Takeoka \& Dao 2002). Hydration of the flavylium cation gives the colorless carbinol pseudobase at $\mathrm{pH}$ values ranging from 3 to 6 . This can further equilibrate to an open form, the colorless chalcone pseudobase.

Processing and storage under low temperature can improve the stability of anthocyanins (Delgado-Vargas \& Paredes-López 2003). Temperature has been reported to induce a slow destruction of the pigments (Delgado-Vargas et al. 2000). When temperature is increased, anthocanins can be transformed into unstable formation of chalcone, and the chalcone is further degraded to brown products.

Light is usually deleterious to anthocyanin components. Palamidis \& Markakis (1975) reported that grape anthocyanins in beverage had the half-life of 416 days in dark against 197 days in daylight at $20^{\circ} \mathrm{C}$. Acylated anthocyanins are less affected by light, with only slight difference on pigment stability when exposed to light as compared to stored in dark (Giusti et al. 1999).

Oxygen and hydrogen peroxide can easily oxidize anthocyanins (DelgadoVargas \& Paredes-López 2003), and this mechanism is often accelerated by the presence of ascorbic acid. The negative impact of ascorbic acid on anthocyanins has been of great concern because of the universality of ascorbic acid in fruit and vegetable juices (Francis 1989). The interaction of ascorbic acid and oxygen may be mediated by $\mathrm{H}_{2} \mathrm{O}_{2}$ because the mechanisms of ascorbic acid oxidation produces peroxide, and peroxide is known to destroy anthocyanins.

Increased sugar level may affect the rate of anthocyanin destruction (Delgado-Vargas \& Paredes-López 2003). It was found that sucrose addition improved the color characteristics of frozen strawberries (Wrolstad et al. 1990). The mechanism could be associated with the inhibition of enzymatic activities of phenolooxidase and peroxidase (Delgado-Vargas \& Paredes-López 2003).

Anthocyanins are very reactive toward metals, and form stable complexes with tin, copper, and iron (Francis 1989). For instance, cyanidin 3-glucoside forms a stable colored complex in the presence of aluminum ions at $\mathrm{pH}$ 5.5. Addition of $\mathrm{AlCl}_{3}$ is an analytical test for anthocyanidins which have two adjacent $\mathrm{OH}$ groups $(\mathrm{Cy}, \mathrm{Pt}, \mathrm{Dp})$ and those which do not (Pg, Pn, Mv).

\section{Determination of anthocyanins}

The most widely used solvents for the extraction of anthocyanins are aqueous solutions of acetone, methanol, and ethanol. The qualitative and quantitative determination of anthocyanins in plant extracts can be achieved by a variety of classical (spectrophotometric) or contemporary methods - HPLC coupled with a various types of mass spectrometers or NMR apparatus. 


\section{Spectrophotometric measurements}

As was described earlier anthocyanin absorption spectra depend on $\mathrm{pH}$. At $\mathrm{pH}$ equal or below 2, anthocyanin solutions show characteristic maxima of absorption, one in the ultraviolet region (approximately 260-280 $\mathrm{nm}$ ) and two in the visible region (approximately 415 and $490-540 \mathrm{~nm}$ ). The wavelengths of these absorbance peaks can differ slightly by a few nanometers among various anthocyanins, depending on structure of each anthocyanin. However, it is not possible to discriminate spectrophotometrically among the various anthocyanins simply on the basis of their absorption spectra. The maximum of absorption at 520 to $540 \mathrm{~nm}$ in the visible region is the most common wavelength used in the spectrophotometric measurement of total anthocyanins (Harborne 1958). The solvent used for spectral determination affects slightly the position of the absorption bands, therefore it must be taken into consideration when comparing available data.

In case of plant material containing anthocyanins and chlorophyll or products of its degradation, optical density at range $650-670 \mathrm{~nm}$ caused by their presence have to be subtracted from values of optical density for anthocyanins. The level of subtraction depends on species and kind of analysed plant tissue, for instance in case of cabbage seedlings from absorbance for anthocyanins at $530 \mathrm{~nm}$ was subtracted 0.25 absorbance at $657 \mathrm{~nm}$ (chlorophylls and products its degradation) $(\mathrm{C}=\mathrm{A} 530-0.25 \cdot \mathrm{A} 657$; Rabino \& Mancinelli 1986). In another paper value of anthocyanin absorbance was corrected by subtraction of 1.15 absorbance value at $640 \mathrm{~nm}(\mathrm{C}=\mathrm{A} 535-1.15 \cdot \mathrm{A} 640$; Sheoran et al. 2006). Since spectrophotometric determination of anthocyanins is rapid and easy, and can also be carried out in raw materials with no sample hydrolysis (or even without homogenization of tissue), it is often adopted to perform a rapid analysis of the total anthocyanin content in plant material. Spectral similarities in the majority of anthocyanins make this determination relatively simple, with the anthocyanins being reported as external standard equivalents; in most of cases, cyanidin-3-glucoside $(\mathrm{C} 3 \mathrm{G})$ - most abundant anthocyanin in nature - is the reference used.

Anthocyanin pigments undergo reversible structural transformations with a change in $\mathrm{pH}$ manifested by different absorbance spectra. The colored oxonium form predominates at $\mathrm{pH} \mathrm{1.0,} \mathrm{and} \mathrm{the} \mathrm{colorless} \mathrm{hemiketal} \mathrm{form} \mathrm{at} \mathrm{pH} 4.5$. This phenomenon was used to more precise anthocyanins determination. The $\mathrm{pH}-$ differential method is based on this reaction, and permits relatively accurate measurement of the total anthocyanins, even in the presence of polymerized and degraded pigments and other interfering compounds. A solution of sodium acetate and $1 \mathrm{~N} \mathrm{HCl}$ is used as $4.5 \mathrm{pH}$ buffer and a solution of $0.2 \mathrm{~N} \mathrm{KCl}$ and $0.2 \mathrm{~N}$ $\mathrm{HCl}$ is used for preparing $1.0 \mathrm{pH}$ buffer (Vangdal et al. 2006, Wrolstad et al. 1982). Real absorbance caused by anthocaynins in sample is calculated using following formula:

$$
\mathrm{A}=\left(\mathrm{A}_{\lambda \max }-\mathrm{A}_{700}\right)_{\mathrm{pH} 1.0}-\left(\mathrm{A}_{\lambda \max }-\mathrm{A}_{700}\right)_{\mathrm{pH} 4.5}
$$

$A_{\lambda \max }$ is absorbance at the wavelength maximum (for instance $530 \mathrm{~nm}$ ), and $A_{700}$ value is subtracted due to presence various phenolics and other background 
substances. The total monomeric anthocyanins are calculated based on the molecular weight and extinction coefficient or molar absorptivity of the most prevalent anthocyanin (usually cyanidin-3-glucoside).

Spectrophotometric procedures, however, are unsatisfactory for precise characterization of the particular anthocyanins present in plant materials. Variability in the sample extraction media (water, acidic water, acidic organic solvent, etc.), chemical properties of anthocyanins, and co-pigmentation of anthocyanins with other secondary metabolites present in the sample solution can cause an inaccurate correlation between absorbance and actual anthocyanin concentration (Bridle \& Timberlake 1997). Moreover, the spectrophotometric method does not provide any specificity as far as the molecular identity of the anthocyanin composition present in the material is concerned.

\section{Analysis of anthocyanins and anthocyanidins by HPLC}

The difficulties related to anthocyanin determination are often associated with sample preparation before analysis. Treatment of anthocyanin-containing material before analysis is highly variable according to the plant material being analysed, as well as the aim of the research. Extraction from dry tissues is usually carried out using water/methanol mixtures acidified by hydrochloric, trifluoroacetic or formic acids, although, for some anthocyanins, excessive acidic conditions may result in partial hydrolysis of the glycosidic moiety (Mazza et al. 2004).

HPLC separation combined with diode array detection (DAD) is the most common contemporary method for qualitative and quantitative analysis of anthocyanins (Gao \& Mazza 1994a). Single wavelength detection is performed at range $520-540 \mathrm{~nm}$, while data acquisition between 200 and $800 \mathrm{~nm}$ is useful when DAD detection is available. Although UV/visible spectra of anthocyanins are quite similar, a tentative identification of compounds can be achieved by comparison with the spectra of reference compounds.

Reversed-phase (RP) columns: $4.6 \mathrm{~mm}$ (internal diameter) and 100-300 $\mathrm{mm}$ (length), are the mostly used in HPLC analysis of anthocyanins. Columns are usually maintained at ambient temperature, and elution systems are binary, using aqueous acidified solvents such as acetic acid, perchloric acid, or formic acid in an organic solvent such as methanol or acetonitrile (Dugo et al. 2001, Zhang et al. 2004). In the reversed-phase system, the more polar phenolic acids elute first, followed by the 3,5-diglycosylated anthocyanins, 3-monoglycosylated anthocyanins, aglycones, and last the acylated anthocyanins. Anthocyanidins elution order on a reversed-phase column is delphinidin, cyanidin, petunidin, pelargonidin, peonidin, and malvidin (Gao \& Mazza 1994b). The retention of glycosides in comparison to that of the aglycones is decreased by the presence of sugars, with diglucosides preceding monoglucosides. Subsequently, acylation increases the retention time of anthocyanins. An examples of HPLC analytical conditions for anthocyanins analyses in fruits and vegetables have been summarized in Table 4 . 
Table 4. Examples of contemporary HPLC analytical conditions useful for determination of anthocyanins in fruits and vegetables

\begin{tabular}{|c|c|c|c|}
\hline $\begin{array}{l}\text { Analysed } \\
\text { tissue }\end{array}$ & $\begin{array}{c}\text { Extraction and purification } \\
\text { of anthocyanins }\end{array}$ & HPLC parameters & Reference \\
\hline $\begin{array}{l}\text { Blueberry } \\
\text { fruits }\end{array}$ & $\begin{array}{l}\text { Extraction mixture: acetone- } \\
\text { methanol-water (35-35-30); } \\
\text { Extract purification: Sep- } \\
\text { Pack cartridges. Anthocya- } \\
\text { nins were eluted with } 70 \% \\
\text { methanol }\end{array}$ & $\begin{array}{l}\text { Detector: DAD; column: } \\
\text { RP-18, } 5 \mu \mathrm{m}, 220 \times 4.6 \mathrm{~mm} \text {; } \\
\text { eluent flow of } 1 \mathrm{ml} \cdot \mathrm{min}^{-1} \text {. } \\
\text { Mobile phase: water (A) : } \\
\text { formic acid (B) : acetonitrile } \\
\text { (C), gradient A and C. }\end{array}$ & $\begin{array}{l}\text { Krupa \& } \\
\text { Tomala } \\
2007\end{array}$ \\
\hline $\begin{array}{l}\text { Bilberry, } \\
\text { blackcurrant } \\
\text { and cowberry } \\
\text { fruits }\end{array}$ & $\begin{array}{l}\text { Extraction mixture: acetoni- } \\
\text { trile - TFA - water } \\
(49.5: 0.5: 50) \text {; Extract purifi- } \\
\text { cation: Amberlite XAD-7 } \\
\text { column chromatography. } \\
\text { Anthocyanins were eluted } \\
\text { with extraction mixture }\end{array}$ & $\begin{array}{l}\text { Detector: DAD; column: } \\
\text { Zorbax SB C18, } 5 \mu \mathrm{m}, 150 \\
\times 4.6 \mathrm{~mm} \text {. Mobile phase: } \\
10 \% \text { formic acid (solvent A) } \\
\text { and } 100 \% \text { acetonitrile (sol- } \\
\text { vent B) (gradient elution) }\end{array}$ & $\begin{array}{l}\text { Kahkonen } \\
\text { et al. } 2003\end{array}$ \\
\hline $\begin{array}{l}\text { Cranberry } \\
\text { fruits }\end{array}$ & $\begin{array}{l}\text { Extraction mixture: ethanol: } \\
1.5 \mathrm{~N} \mathrm{HCl}(85: 15, \mathrm{v} / \mathrm{v}) \\
\text { filtration - no purification }\end{array}$ & $\begin{array}{l}\text { Detector: DAD; Column: } \\
\text { C18, } 5 \mu \mathrm{m}(4.6 \times 150 \mathrm{~mm}) \\
\text { Mobile phase: linear gradi- } \\
\text { ent of }(\mathrm{A}) \text { water - acetic acid } \\
(10: 1) \text { and }(\mathrm{B}) \text { methanol- } \\
\text { acetic acid }(10: 1)\end{array}$ & $\begin{array}{l}\text { Zhou \& } \\
\text { Singh } 2004\end{array}$ \\
\hline Mulberry fruits & $\begin{array}{l}\text { Mulberry juice was purified } \\
\text { on cross-linked polystyrene } \\
\text { resins; Anthocyanins were } \\
\text { eluted from the resins with } \\
\text { etanol acidified by } 0.5 \% \\
\text { hydrochloric acid }\end{array}$ & $\begin{array}{l}\text { Detector: DAD; Column: } \\
\text { C18, } 3 \mu \mathrm{m}(4.6 \times 100 \mathrm{~mm}) \text {; } \\
\text { Mobile phase: linear gradi- } \\
\text { ent elution with } 25-85 \% \\
\text { solvent B }(1.5 \% \text { phosphoric } \\
\text { acid, } 20 \% \text { acetic acid, } 25 \% \\
\text { acetonitrile) in solvent A } \\
(1.5 \% \text { phosphoric acid }) \text { for } \\
100 \text { min. }\end{array}$ & $\begin{array}{l}\text { Liu et al. } \\
2004\end{array}$ \\
\hline $\begin{array}{l}\text { Elderberry and } \\
\text { blackberry } \\
\text { juices; black } \\
\text { carrot and red } \\
\text { cabbage con- } \\
\text { centrates }\end{array}$ & $\begin{array}{l}\text { Juices and concentrates were } \\
\text { diluted with water, and } \\
\text { purified on C18 Sep-Pack } \\
\text { cartridges; anthocyanins } \\
\text { were eluted from cartridges } \\
\text { with methanol containing } \\
0.01 \% \text { aqueous } \mathrm{HCl}\end{array}$ & $\begin{array}{l}\text { Detector: DAD; Column: } \\
\text { C18 reversed-phase, } 5 \mu \mathrm{m} \\
(250 \times 4.6 \mathrm{~mm}) \text {; Mobile } \\
\text { phase: B }(90 / 10 \text { - acetoni- } \\
\text { trile/water) and A ( } 10 \% \\
\text { aqueous formic acid). Sepa- } \\
\text { ration by linear gradient } \\
\text { starting with } 93 \% \text { A to } 85 \% \\
\text { A in } 18 \text { min, and then to } \\
50 \% \text { A in } 7 \text { min. }\end{array}$ & $\begin{array}{l}\text { Stintzing } \\
\text { et al. } 2002\end{array}$ \\
\hline
\end{tabular}

Another modern method uses electrospray ionization mass spectrometry technique (ESI-MS) for anthocyanin characterisation in complex food matrices (Giusti et al. 1999). The method is especially useful for detection of low level anthocyanin metabolites in human plasma. This method uses low voltage as well as atmospheric pressure, and is versatile as an ionisation technique. The 
positive charge of anthocyanins at low $\mathrm{pH}$ values permits their easy detection using low voltages since other potentially interfering compounds are not usually ionised. ESI-MS is a very powerful tool for anthocyanin characterization and monitoring the authenticity of anthocyanin-containing fruit juices and vegetable extracts.

Direct HPLC analysis of plant anthocyanins as glycosides could result in a chromatogram with a large number of peaks, making it difficult to identify individual components. Due to the huge variability of the sugars and organic acids forming the glycosidic moiety, the number of anthocyanins present in a sample can be even 15-20 times greater than the number of aglycone forms. It is possible to solve this problem by choosing a reference glycoside that has a known molar extinction coefficient for calibration (Chandra et al. 2001). In this case, it is important to select a reference compound with the same aglycone moiety of the predominant anthocyanin in the sample.

In order to measure the definitive anthocyanidins composition and concentration in a sample, is used a method to release the aglycone from an anthocyanin molecule by acid hydrolysis, which reduces the number of peaks on the chromatogram. Optimal anthocyanin hydrolysis is carried out by heating samples in methanol containing $1-3 \mathrm{M} \mathrm{HCl}$, in a boiling water bath or heating blocks for 20-60 minutes. Anthocyanidins from hydrolyzed samples can be extracted with isoamyl alcohol (Mazza et al. 2004).

Many other details of contemporary, modern procedures of anthocyanins analyses have been described in excellent review by Mazza et al. (2004). Liquid chromatography with mass spectrometry (MS) and/or nuclear magnetic resonance (NMR) spectroscopy are possibly the most powerful methods for the structural elucidation of anthocyanins.

\section{Daily intake and role of anthocyanins in maintaining health}

Anthocyanins are widely ingested by humans, mainly due to consumption of fruits, vegetables and red wines (Galvano et al. 2004). Depending on the nutritional habits, the daily intake of anthocyanins for individuals has been estimated to range from several milligrams to hundreds of milligrams per person. In USA, average daily intake of anthocyanins has been estimated at $215 \mathrm{mg}$ during summer and $180 \mathrm{mg}$ during winter (Clifford 2000). The daily intake of other flavonoids including quercetin, myricetin, kaempferol, luteolin and apigenin is estimated to be only $20-22 \mathrm{mg} \cdot \mathrm{day}^{-1}$ in the US citizens (Sampson et al. 2002, Kühnau 1976).

Intake of anthocyanin is increasing because extracts and juices with high anthocyanin contents from fruits and vegetables are now much more commercially available, than earlier. Due to the antioxidant and other potential beneficial properties, grape, various berries, red cabbage and other anthocyanin rich foods are becoming more popular. In the future, the production and adding of anthocyanins as natural food colorants is expected to steadily increase, following the current trend away from synthetic colors (Gao \& Mazza 1994a).

Flavonoids (flavonols, flavones, anthocyanins) occuring in fruits and vegetables are protective against a variety of diseases, particularly cardiovascular dis- 
ease and some types of cancer (Ness \& Powles 1997). Anthocyanins are implicated in many biological activities that may impact positively on human health (Lila 2004). Their use for therapeutic purposes has long been supported by epidemiological evidence, but only in recent years some of the specific, measurable pharmacological properties of isolated anthocyanin pigments have been verified by controlled in vitro, in vivo, or clinical research studies (Lila 2004).

These pigments may reduce the risk of coronary heart disease through inhibition of platelet aggregation (Rechner \& Kroner 2005). Anthocyanins protect in several ways. First, they neutralize enzymes that destroy connective tissue. Second, their antioxidant capacity prevents oxidants from damaging connective tissue. Finally, they repair damaged proteins in the blood-vessel walls.

In many other cases, the exact roles of the anthocyanins in human health maintenance versus other phytochemicals in a complex mixture from a fruit extract or whole food have not been completely sorted out. In fact, some reports suggest that anthocyanin activity potentates when it is delivered in mixtures (Stintzing et al. 2002). Visual acuity can be markedly improved through administration of anthocyanin pigments to animals and humans, and the role of these pigments in enhancing night vision or overall vision has been particularly well documented (Lila 2004). Oral intake of anthocyanins from black currants resulted in significantly improved night vision adaptation in human subjects (Nakaishi et al. 2000). However others studies show that anthocyanins did not improve three measures of night vision (Zadok et al. 1999). For instance in a NASA study was found that daily using $40 \mathrm{mg}$ bilberry anthocyanins had no effect in night vision, visual acuity, or contrast sensitivity compared with placebo (Muth et al. 2000).

The antioxidant capacity of anthocyanins has been demonstrated with a wide variety of assay methods. Berry extracts demonstrated potent antioxidant activities that correlated with anthocyanin content (Olsson et al. 2004). According to Cooke et al. (2005) the structure-antioxidant pattern indicates that potent antioxidant activity is associated with presence of hydroxyl groups in the anthocyanin B-ring. The antioxidant capacities of cyanidin and cyanidin 3-glucosides were similar to $\alpha$-tocopherol in assay systems of linolenic acid, liposomes, rabbit erythrocyte membranes and rat liver microsomes (Tsuda et al. 1994).

In addition, anthocyanins could exert anticarcinogenic activities, reduce inflammatory insult and also modulate immune response. All these effects might be mediated by their antioxidant activity (Hou 2003). In the laboratory experiments have been found that cyanidin and delphinidin inhibit epidermal growth factor receptor in cancer cells, while malvidin is less effective (Meiers et al. 2001).

\section{Acknowledgement}

Preparation of the review was partly supported by grant obtained from Ministry of Science and Higher Education, Republic of Poland (grant: N 310040 31/2125) 


\section{REFERENCES}

Ancos B., Gonzalez E., Cano M.P. 1999. Differentiation of raspberry varieties according to anthocyanin composition. Z. Lebensm. Unters Forsch. A 208: 33-38.

Arabbi P.R., Genovese M.I., Lajolo F.M. 2004. Flavonoids in vegetable foods commonly consumed in Brazil and estimated ingestion by the Brazilian population. J. Agric. Food Chem. 52: 1124-1131. [DOI: 10.1021/jf0499525]

Bridle P., Timberlake C.F. 1997. Anthocyanins as natural food colours - selected aspects. Food Chem. 58: 103-109. [DOI:10.1016/S0308-8146(96)00222-1]

Brouillard R. 1982. Chemical structure of anthocyanins. In "Anthocyanins as food colors". (Markakis P., eds.) Academic Press, New York, pp. 1-40.

Brouillard R., Dangles O. 1994. Anthocyanin molecular interactions: the first step in the formation of new pigments during wine aging? Food Chem. 51: 365-371. [DOI:10.1016/0308-8146(94)90187-2]

Chalker-Scott L. 1999. Environmental significance of anthocyanins in plant stress response. Photochem. Photobiol. 70: 1-9. [DOI:10.1111/j.1751-1097.1999.tb01944.x]

Chandra A., Rana J., Li Y. 2001. Separation, identification, quantification method validation of anthocyanins in botanical supplement raw materials by HPLC and HPLC-MS. J. Agric. Food Chem. 49: 3515-3521. [DOI: 10.1021/jf010389p]

Clifford M.N. 2000. Anthocyanins - nature, occurrence and dietary burden. J. Sci. Food Agric. 80:1063-1072. [DOI: 10.1002/(SICI)1097-0010(20000515)80:7<1063::AID-JSFA605>3.0.CO;2-Q]

Cooke D., Steward W.P., Gescher A.J., Marczylo T. 2005. Anthocyans from fruits and vegetables-does bright colour signal cancer chemopreventive activity? Eur. J. Cancer 41: 1931-1940. [DOI:10.1016/j.ejca.2005.06.009]

Dangles O., Saito N., Brouillard R. 1993. Anthocyanin intramolecular copigment effect. Phytochemistry 34: 119-124. [DOI:10.1016/S0031-9422(00)90792-1]

Delgado-Vargas F., Jiménez A.R., Paredes-López O. 2000. Natural pigments: carotenoids, anthocyanins, and betalains - characteristics, biosynthesis, processing and stability. Crit. Rev. Food Sci Nutr. 40: 173-289.

[DOI: 10.1080/10408690091189257]

Delgado-Vargas F., Paredes-López O. 2003. Anthocyanins and betalains. In "Natural Colorants for Food and Nutraceutical Uses". CRC Press, Boca Raton, pp: 167-219.

Dugo P., Mondello L., Errante G., Zappia G., Dugo G. 2001. Identification of anthocyanins in berries by narrow-bore high-performance liquid chromatography with electrospray ionization detection. J. Agric. Food Chem. 49: 3987-3992. [DOI: $10.1021 / \mathrm{jf001495e]}$

Eder A. 2000. Pigments in food analysis by HPLC. (Nollet M.L.L. eds.) Marcel Dekker, New York, pp. 845-880.

Fan-Chiang H-J., Wrolstad R.E. 2005. Anthocyanin pigment composition of blackberries. J. Food Sci. 70: C198-C202. [DOI:10.1111/j.1365-2621.2005.tb07125.x]

Ferreres F., Gil M.I., Tomás-Barberán F.A. 1996. Anthocyanins and flavonoids from shredded red onion and changes during storage in perforated films. Food Res. Int., 29: 389-395. [DOI:10.1016/0963-9969(96)00002-6]

Francis F.J. 1989. Food colorants: anthocyanins. Crit. Rev. Food Sci. Nutr. 28: 273-314.

Franke A.A., Custer L.J., Arakaki C., Murphy S.P. 2004. Vitamin C and flavonoid levels of fruits and vegetables consumed in Hawaii. J. Food Comp. Anal. 17: 1-35. [DOI:10.1016/S0889-1575(03)00066-8] 
Galvano F., Fauci L.L., Lazzarino G., Fogliano V., Ritieni A., Ciappellano S., Battistini N.C., Tavazzi B., Galvano G. 2004. Cyanidins: metabolism and biological properties. J. Nutr. Biochem. 15: 2-11. [DOI:10.1016/j.jnutbio.2003.07.004]

Gao L., Mazza G. 1994a. Quantitation and distribution of simple and acylated anthocyanins and other phenolics in blueberries. J. Food Sci. 59: 1057-1059. [DOI:10.1111/j.1365-2621.1994.tb08189.x]

Gao L., Mazza G. 1994b. Rapid method for complete chemical characterization of simple and acylated anthocyanins by high-performance liquid chromatography and capillary gas-liquid chromatography. J. Agric. Food Chem. 42: 118-125.

[DOI: 10.1021/jf00037a020]

Garcia-Vigera C., Zafrilla P., Tomás-Barberán F.A. 1998. The use of acetone as an extraction solvent for anthocyanins from strawberry fruit. Phytochem. Anal. 9: 274-277.

[DOI: 10.1002/(SICI)1099-1565(199811/12)9:6<274::AID-PCA416>3.0.CO;2-G]

Gennaro L., Leonardi C., Esposito F., Salucci M., Maiani G., Quaglia G., Fogliano V. 2002. Flavonoid and carbohydrate contents in tropea red onions: Effects of homelike peeling and storage. J. Agric. Food Chem. 50: 1904-1910.

[DOI: $10.1021 / \mathrm{jf0} 11102 \mathrm{r}$ ]

Giusti M.M., Ghanadan H., Wrolstad R.E. 1998. Elucidation of the structure and conformation of red radish (Raphanus sativus) anthocyanins using one- and two dimensional nuclear magnetic resonance techniques. J. Agric. Food Chem. 46: 4858-4863. [DOI: 10.1021/jf980695b]

Giusti M.M., Rodríguez-Saona L.E., Griffin D., Wrolstad R.E. 1999. Electrospray and tandem mass spectroscopy as tools for anthocyanin characterization. J. Agric. Food Chem. 47: 4657-4664. [DOI: 10.1021/jf981242+]

Goto T., Kondo T. 1991. Structure and molecular stacking of anthocyanins - flower color variation. Angew. Chem. Int. Ed. Engl. 30: 17-33.

Gould K.S. 2004. Nature's swiss army knife: The diverse protective roles of anthocyanins in leaves. J. Biomed. Biotechnol. 5: 314-320.

[DOI:10.1155/S1110724304406147]

Harborne J.B. 1958. Spectral methods of characterizing anthocyanins. Biochemical J. 70: $22-28$.

Harborne J.B. 1998. Phenolic compounds in phytochemical methods - a guide to modern techniques of plant analysis. Third edition. Chapman \& Hall, New York, pp. 66-74.

Harborne J.B., Williams C.A. 2001. Anthocyanins and other flavonoids. Nat. Prod. Rep. 18: 310-333. [DOI: 10.1039/b006257j]

Harnly J.M., Doherty R., Beecher G.R., Holden J.M., Haytowitz D.B., Bhagwat S. 2006. Flavonoid content of U.S. fruits, vegetables, and nuts. J. Agric. Food Chem. 54: 9966-9977. [DOI: 10.1021/jf061478a]

Heredia F.J., Francia-Aricha E.M., Rivas-Gonzalo J.C., Vicario I.M., Santos-Buelga C. 1998. Chromatic characterization of anthocyanins from red grapes - I. pH effect. Food Chem. 63: 491-498. [DOI:10.1016/S0308-8146(98)00051-X]

Hou D.-X. 2003. Potential mechanisms of cancer chemoprevention by anthocyanins. Curr. Molec. Med. 3: 149-159.

Iversen C.K. 1999. Black currant nectar: Effect of processing and storage on anthocyanin and ascorbic acid content. J. Food Sci. 64: 37-41. [DOI:10.1111/j.1365-2621.1999.tb09856.x]

Kaack K., Austed T. 1998. Interaction of vitamin C and flavonoids in elderberry (Sambucus nigra L.) during juice processing. Plant Foods Hum. Nutr. 52: 187-19. 
[DOI 10.1023/A:1008069422202]

Kahkonen M.P., Heinamaki J., Ollilainen V., Heinonen M. 2003. Berry anthocyanins: isolation, identification, and antioxidant activities. J. Sci. Food Agric. 83: 14031411. [DOI: 10.1002/jsfa.1511]

Kong J.-M., Chia L.-S., Goh N.-K., Chia T.F., Brouillard R. 2003. Analysis and biological activities of anthocyanins. Phytochemistry 64: 923-933. [DOI:10.1016/S0031-9422(03)00438-2]

Kühnau J. 1976. The flavonoids. A class of semi-essential food components: their role in human nutrition. World Rev. Nutr. Diet. 24: 117-191.

Krupa T., Tomala K. 2007. Antioxidant capacity, anthocaynin kontent profile in 'Bluecrop" blueberry fruit. Veget. Crops Res. Bull. 66: 129-141. [DOI: $10.2478 / \mathrm{v} 10032-007-0015-7]$

Lila M.A. 2004. Anthocyanins and human health: an in vitro investigative approach. J. Biomed. Biotechnol. 5: 306-313. [DOI:10.1155/S111072430440401X]

Liu X., Ciao G., Chen W., Xu Y., Wu J. 2004. Quantification and purification of mulberry anthocyanins with macroporous resins. J. Biomed. Biotech. 5: 326-331. [DOI:10.1155/S1110724304403052]

Maatta K.R., Kamal-Eldin A., Torronen A.R. 2003. High-Performance liquid chromatography (HPLC) analysis of phenolic compounds in berries with diode array and electrospray ionization mass spectrometric (MS) detection: Ribes species. J. Agric. Food Chem. 51: 6736-6744. [DOI: 10.1021/jf0347517]

Mazza G., Cacace J.E., Kay C.D. 2004. Methods of analysis for anthocyanins in plants and biological fluids. J. AOAC Internat. 87: 129-145.

Mazza G., Miniati E. 1993. Anthocyanins in fruits, vegetables and grains, CRC Press: London, U.K.

Meiers S., Kemeny M., Weyand U., Gastpar R., Angerer E., Marko D. 2001. The anthocyanidins: cyanidin and delphinidin are potent inhibitors of the epidermal growth-factor receptor. J. Agric. Food Chem. 49: 958-962. [DOI: 10.1021/jf0009100]

Mullen W., Stewart A.J., Lean M.E.J., Gardner P., Duthie G.G., Crozier A. 2002. Effect of freezing and storage on the phenolics, ellagitannins, flavonoids, and antioxidant capacity of red raspberries. J. Agric. Food Chem. 50: 5197-5201. [DOI: 10.1021/jf020141f]

Muth E.R., Laurent J.M., Jasper P. 2000. The effect of bilberry nutritional supplementation on night visual acuity and contrast sensitivity. Altern. Med. Rev. 5: 164-73.

Nakaishi H., Matsumoto H., Tominaga S., Hirayama M. 2000. Effects of blackcurrant anthocyanoside intake on dark adaptation and VDT work-induced transient refractive alternation in healthy humans. Altern. Med. Rev. 5: 553-562.

Ness A.R., Powles J.W. 1997. Fruit and vegetables, and cardiovascular disease: a review. Int. J. Epidemiol. 26: 1-13. [DOI: 10.1093/ije/26.1.1]

Olsson M.E., Gustavsson K.E., Andersson S., Nilsson A., Duan R.D. 2004. Inhibition of cancer cell proliferation in vitro by fruit and berry extracts and correlations with antioxidant levels. J. Agric. Food Chem. 52: 7264-7271. [DOI: 10.1021/jf030479p]

Palamidis N., Markakis P. 1975. Stability of grape anthocyanin in a carbonated beverage. J. Food Sci. 40: 1047-1048. [DOI: 10.1111/j.1365-2621.1975.tb02264.x]

Prior R.L. 2004. Absorption and metabolism of anthocyanins: potential health effects in phytochemicals - mechanisms of action. In "Phytochemicals: mechanism of action". (Meskin M.S., Bidlack W.R., Davies A.J., Lewis D.S., Randolph R.K. Eds.) CRC Press, Boca Raton, pp. 1-19. 
Rabino I., Mancinelli A.L. 1986. Light, temperature, and anthocyanin production. Plant Physiol. 81: 922-924.

Rechner A.R., Kroner C. 2005. Anthocyanins and colonic metabolites of dietary polyphenols inhibit platelet function. Thromb. Res. 116: 327-334.

[DOI: 10.1016/j.thromres.2005.01.002]

Revilla E., Ryan J-M., Martin-Ortega G. 1998. Comparison of several procedures used for the extraction of anthocyanins from red grapes. J. Agric. Food Chem. 46: 4592-4597. [DOI: 10.1021/jf9804692]

Romani A., Vignolini P., Galardi C., Mulinacci N., Benedettelli S., Heimler D. 2004. Germplasm characterization of zolfino landraces (Phaseolus vulgaris L.) by flavonoid content. J. Agric. Food Chem. 52: 3838-3842. [DOI: 10.1021/jf0307402]

Sampson L., Rimm E., Hollman P.C., de Vries J.H., Katan M.B. 2002. Flavonol and flavone intakes in US health professionals. J. Am. Diet. Assoc. 102: 1414-1420. [DOI: 10.1016/S0002-8223(02)90314-7]

Sheoran I.S., Dumonceaux T., Datla R., Sawhney V.K. 2006. Anthocyanin accumulation in the hypocotyl of an ABA-over producing male-sterile tomato (Lycopersicon esculentum) mutant. Physiol. Plantarum 127: 681-689.

[DOI: 10.1111/j.1399-3054.2006.00697.x]

Slimestad R., Toskangerpoll K., Nateland H.S., Johannessen T., Giske N.H. 2005. Flavonoids from black chokeberries, Aronia melanocarpa. J. Food Comp. Anal. 18: 61-68. [DOI: 10.1016/j.jfca.2003.12.003]

Stintzing F.C., Stintzing A.S., Carle R., Frei B., Wrolstad R.E. 2002. Color and antioxidant properties of cyanidin-based anthocyanin pigments. J. Agric. Food. Chem. 50: 6172-6181. [DOI: 10.1021/jf0204811]

Takeoka G., Dao L. 2002. Anthocyanins. In "Methods of analysis for functional foods and nutraceuticals". (Hurst W.J. eds.) CRC press, Boca Boton 2002, pp. 219-241.

Timberlake C.F., Henry B.S. 1988. Anthocyanins as natural food colorants. Prog. Clin. Biol. Res. 280: 107-121.

Tsuda T., Watanabe M., Ohshima K., Norinobu S., Choi S., Kawakishi S., Osawa T. 1994. Antioxidative activity of the anthocyanin pigments cyanidin 3-O-glucoside and cyanidin. J. Agric. Food Chem. 42: 2407-2410. [DOI: 10.1021/jf00047a009]

USDA 2007. Database for the Flavonoid content of Selected Foods. Release 2.1. January 2007; http://www.nal.usda.gov/fnic/foodcomp/Data/Flav/Flav02-1.pdf

Vangdal E., Slimestad R., Sekse L. 2006. The content of phenolics in sweet cherries (Prunus avium L.) related to cultivar and stage of maturity. Veget. Crops Res. Bull. 65: 169-175.

Wang H., Nair M.G., Iezzoni A.F., Strasburg G.M., Booren A.M., Gray I. 1997. Quantification and characterization of anthocyanins in Balaton tart cherries. J. Agric. Food Chem. 45: 2556-2560. [DOI: 10.1021/jf960896k]

Wang S.Y., Zheng W., Galleta G. 2002. Cultural system affects fruit quality and antioxidant capacity in strawberries. J. Agric. Food Chem. 50: 6534-6542. [DOI: $10.1021 / \mathrm{jf020614i]}$

Wang S.Y., Lin H-S. 2003. Compost as a soil supplement increases the level of antioxidant compounds and oxygen radical absorbance capacity in strawberries. J. Agric. Food Chem. 51: 6844-6850. [DOI: 10.1021/jf030196x]

Wrolstad R.E., Culbertson J.D., Cornwell C.J., Mattick L.R. 1982. Detection of adulteration in blackberry juice concentrates and wines. J. Assoc. Off. Anal. Chem. 65: 1417-1423.

Wrolstad R.E., Skrede G.L., Lea P., Enersen G. 1990. Influence of sugar on anthocyanin pigment stability in frozen strawberries. J. Food Sci. 55: 1064-1065, 1072. 
[DOI: 10.1111/j.1365-2621.1990.tb01598.x]

Wu X., Beecher G.R., Holden J.M., Haytowitz D.B., Gebhardt S.E., Prior R.L. 2006. Concentrations of anthocyanins in common foods in the United States and estimation of normal consumption. J. Agric. Food Chem. 54: 4069-4075.

[DOI: $10.1021 / \mathrm{jf0603001]}$

Wu X., Gu L., Prior R.L., McKay S. 2004. Characterization of anthocyanins and proanthocyanidins in some cultivars of Ribes, Aronis, and Sambucus and their antioxidant capacity. J. Agric. Food Chem. 52: 7846-7856. [DOI: 10.1021/jf0486850]

Zadok D., Levy Y., Glovinsky Y. 1999 The effect of anthocyanosides in a multiple oral dose on night vision. Eye Dec. 13: 734-736.

Zhang Z., Kou X., Fugal K., McLaughlin J. 2004. Comparison of HPLC methods for determination of anthocyanins and anthocyanidins in bilberry extracts. J. Agric. Food Chem. 52: 688-691. [DOI: 10.1021/jf034596w]

Zhou Y., Singh B.R. 2004. Effect of light on anthocyanin levels in submerged, harvested cranberry fruit. J. Biomed. Biotech. 5: 259-263.

[DOI: $10.1155 / \mathrm{S} 1110724304403027$ ]

\title{
ANTOCYJANY W OWOCACH I WARZYWACH - ICH WYSTĘPOWANIE, METODY ANALIZY I ROLA W ŻYWIENIU CZŁOWIEKA
}

\begin{abstract}
Streszczenie
Antocyjany są jedną z największych i najważniejszych grup barwników, występujących w większości gatunków roślin. Są one akumulowane w wakuolach komórek i odpowiadają za różnorakie wybarwienie, od pomarańczowego do czerwonego i od purpurowego do niebieskiego, kwiatów, owoców i warzyw, takich jak: jeżyna, czarna porzeczka, borówka, wiśnia, winogrona, cebula czerwona, rzodkiewka, kapusta czerwona, sałata czerwona, oberżyna, słodkie ziemniaki. Antocyjany występują w owocach i warzywach $\mathrm{w}$ formie glikozydów. Metody ilościowego i jakościowego oznaczania antocyjanów obejmują techniki spektrofotometryczne oraz chromatograficzne (HPLC) połączone z różnego rodzaju spektrometrami masowymi lub magnetycznym rezonansem jądrowym. Głównym źródłem antocyjanów w pożywieniu są owoce, warzywa oraz czerwone wino. Zależnie od nawyków żywieniowych dzienne spożycie antocyjanów jest oceniane na około kilkanaście do kilkuset miligramów na osobę. Antocyjany, podobnie jak i inne flawonoidy, oddziałują korzystnie jako czynnik zapobiegawczy, przeciw chorobom układu krażenia oraz niektórym chorobom nowotworowym. Mają również wpływ na poprawę ostrości wzroku.
\end{abstract}

